\title{
Synthesis, Crystal Structure, and Characterization of the first Organic Cation Hexaoxoperiodate
}

\author{
I. Wacharine, W. Smirani Sta*, M. Rzaigui \\ Laboratoire de chimie des matériaux, Faculté des sciences de Bizerte, 7021, \\ Zarzouna, Tunisia \\ *Corresponding author: wajda_sta@yahoo.fr
}

\section{ABSTRACT}

The title compound is an organic-inorganic hybrid material. The single crystal X-ray diffraction investigation reveals that the studied compound crystallizes in the monoclinic system, space group $P 2{ }_{1} / c$ with the following lattice parameters: $a=7.551$ (2) $\AA, b=6.694$ (3) $\AA, c=14.783$ (2) $\AA, \beta=97.61$ (2) ${ }^{\circ}$ and $Z=2$. The crystal lattice is composed of a discrete $\left(\mathrm{H}_{4} \mathrm{IO}_{6}\right)$ - anions surrounded by piperazinium cations and water molecules. Complex hydrogen bonding interactions between the different chemical spices form a three-dimensional network. Room temperature IR, ${ }^{13} \mathrm{C}$ NMR spectroscopy, thermogravimetric analysis and optical absorption of the title compound were recorded and analyzed.

\section{Indexing terms/Keywords}

First organic cation periodate; Crystal structure; IR Spectroscopy; Thermogravimetric analysis; ${ }^{13} \mathrm{C}$ NMR.

\section{Council for Innovative Research}

Peer Review Research Publishing System

\section{Journal: Journal of Advances in Chemistry}

Vol. 9, No. 1

editorjaconline@gmail.com

$\underline{\text { www.jac.cirworld.com, member.cirworld.com }}$ 


\section{INTRODUCTION}

The chemistry of periodic acid is rather complex as a great number of periodate oxo-anions $\mathrm{H}_{\mathrm{X}} \mathrm{IO}_{6}{ }^{(5-\mathrm{x}) \text { - }}$ have been elaborated and structurally investigated [1-2]. $\mathrm{IO}_{4}{ }^{-}$anion is called metaperiodate, $\mathrm{H}_{4} \mathrm{IO}_{6}{ }^{-}, \mathrm{H}_{3} \mathrm{IO}_{6}{ }^{2-}, \mathrm{H}_{2} \mathrm{IO}_{6}{ }^{3-}, \mathrm{HIO}_{6}{ }^{4-}$ and $\mathrm{IO}_{6}{ }^{5-}$ anions are called orthoperiodates. $\mathrm{H}_{4} \mathrm{IO}_{6}{ }^{-}$anion is known only with a limited number of cations. Sebert characterized some compounds containing anions by IR and Raman spectroscopy, but no detailed structural analysis can be found due to twining of the crystals. Recently, $\mathrm{Sr}\left(\mathrm{H}_{4} \mid \mathrm{O}_{6}\right)_{2} \cdot 3 \mathrm{H}_{2} \mathrm{O}$ [1] and $\mathrm{Be}\left(\mathrm{H}_{4} \mathrm{IO}_{6}\right)_{2} \cdot 4 \mathrm{H}_{2} \mathrm{O}$ [2] are structurally characterized on single crystals. In literature, there are some organic cations metaperiodates [3]. Up to now, there is no organic cation orthoperiodate structurally well characterised. At our acknowledgement the title compound, $\left(\mathrm{C}_{4} \mathrm{H}_{12} \mathrm{~N}_{2}\right)\left(\mathrm{H}_{4} \mathrm{IO}_{6}\right)_{2} .2 \mathrm{H}_{2} \mathrm{O}$, is the first one of this family. We report here its synthesis and crystal structure. Piperazine and some derivates are biologically active across a number of different therapeutic areas [4] such as antifungal, antibacterial, antimalarial, antipsychotic, antidepressant and antitumour activity against colon, prostate, breast, lung and leukemia tumors [5].

\section{EXPERIMENTAL}

\subsection{Material Preparation}

Crystals of piperazinium bis-tetrahydrogen-hexaoxoperiodate dihydrate were obtained by mixing, in stoichiometric ratio, a solution of periodic acid $(1 \mathrm{M})$ with an aqueous solution of piperazine $(0,4 \mathrm{~g})$. The mixture was stirred for 5 hours, and then the precipitated was filtered. The obtained solution was slowly evaporated at room temperature. After 2 weeks of evaporation at $278 \mathrm{~K}$, colorless prism shaped crystals appear in the solution.

\subsection{Physical measurement}

X-ray diffraction measurements were collected using CAD4 diffractometer MACH III, (graphite-monochromated Ag. Ka radiation $\lambda=0.56087 \AA$ ). All calculations were performed using SHELXL97 [6] for structure determination and refinement. The positional parameters of the iodine atoms were obtained from the three-dimensional Patterson map, whereas the remaining atoms were found from successive refinement and difference-Fourier synthesis. After introducing anisotropic thermal factors for the non hydrogen atoms and isotropic ones for $\mathrm{H}$ atoms $[\mathrm{O}-\mathrm{H}$ bond distances and distances between two atoms from each water molecule were restrained to be $0.85(2)$ and $1.37(2) \AA$, with $\left.U_{\text {iso }}(H)=1.5 U_{\text {eq }}(O)\right]$, the final refinement cycles led to $R_{1}=0.062$ and $w R_{2}=0.156$.

The infrared spectrum of the $\left(\mathrm{C}_{4} \mathrm{H}_{12} \mathrm{~N}_{2}\right)\left(\mathrm{H}_{4} \mathrm{IO}_{6}\right)_{2} .2 \mathrm{H}_{2} \mathrm{O}$ was recorded on a Nicolet IR200 FT-IR Spectrometer at ambient temperature.

The thermogravimetric measurements were performed with the use of the multimodule 92 Setaram analyzer apparatus in the $25-500{ }^{\circ} \mathrm{C}$ temperature range in the argon flow. The rate of heating was $5^{\circ} \mathrm{C} / \mathrm{min}$; the mass of the sample was $13.83 \mathrm{mg}$.

The UV adsorption and optical diffuse reflectance spectra were measured at room temperature with a Perkin Elmer Lambda 11 UV/Vis spectrophotometer in the range of 200-800 $\mathrm{nm}$.

The ${ }^{13} \mathrm{C}$ NMR spectra was measured with a Bruker ULTRASHIELD PLUS 500 spectrometer

\section{RESULTS AND DISCUSSION}

\subsection{X-ray diffraction analysis}

Crystal data summary of intensity data collection and structure refinement are reported in Table 1.

The piperazinium bis-tetrahydrogen-hexaoxoperiodate dihydrate (I) has an asymmetric unit built of one $\mathrm{H}_{4} \mathrm{IO}_{6}{ }^{-}$anion, one half of piperazinium cation and one water molecule (Figure 1). $\mathrm{H}_{4} \mathrm{OO}_{6}{ }^{-}$anions are coupled into pairs through $\mathrm{H}$-bonds $\mathrm{O} 2-\mathrm{H} 7 \ldots \mathrm{O} 3$. The formed dimmers are connected by $\mathrm{O} 4-\mathrm{H} 4 \ldots \mathrm{O} 1$ to built layers parallel to $(\mathrm{b}, \mathrm{c})$ plane at $\mathrm{x}=0$. These layers are interconnected with the water molecules and piperazinium dications via $\mathrm{Ow}-\mathrm{H} \ldots \mathrm{O}, \mathrm{N}-\mathrm{H} \ldots \mathrm{O}$ and $\mathrm{C}-\mathrm{H} \ldots \mathrm{O}$ hydrogen bonds (Figure 2). In this hydrogen bonding, the water molecules play a double role, acceptor in $\mathrm{O} 5-\mathrm{H} 5 \ldots \mathrm{O} 7 \mathrm{and}$ donor in $\mathrm{O} 7-\mathrm{H} 15 \ldots \mathrm{O} 5$ and $\mathrm{O} 7-\mathrm{H} 14 \ldots \mathrm{O} 3$. In the $\mathrm{IO}_{6}$ octahedra, there are two groups of distances (I-O) short distances ranging from $1.807(4)$ and $1.820(3) \AA$ and four longer distances between $1.891(3)$ and $1.916(3) \AA$. The longer distances $1-$ $\mathrm{O}$ correspond to oxygen atoms $\mathrm{O}(2), \mathrm{O}(4), \mathrm{O}(5)$ and $\mathrm{O}(6)$ carry hydrogen in $\mathrm{H}_{4} \mathrm{IO}_{6}^{-}$anion (Table 2). 
Table 1. Crystal data and structure refinement

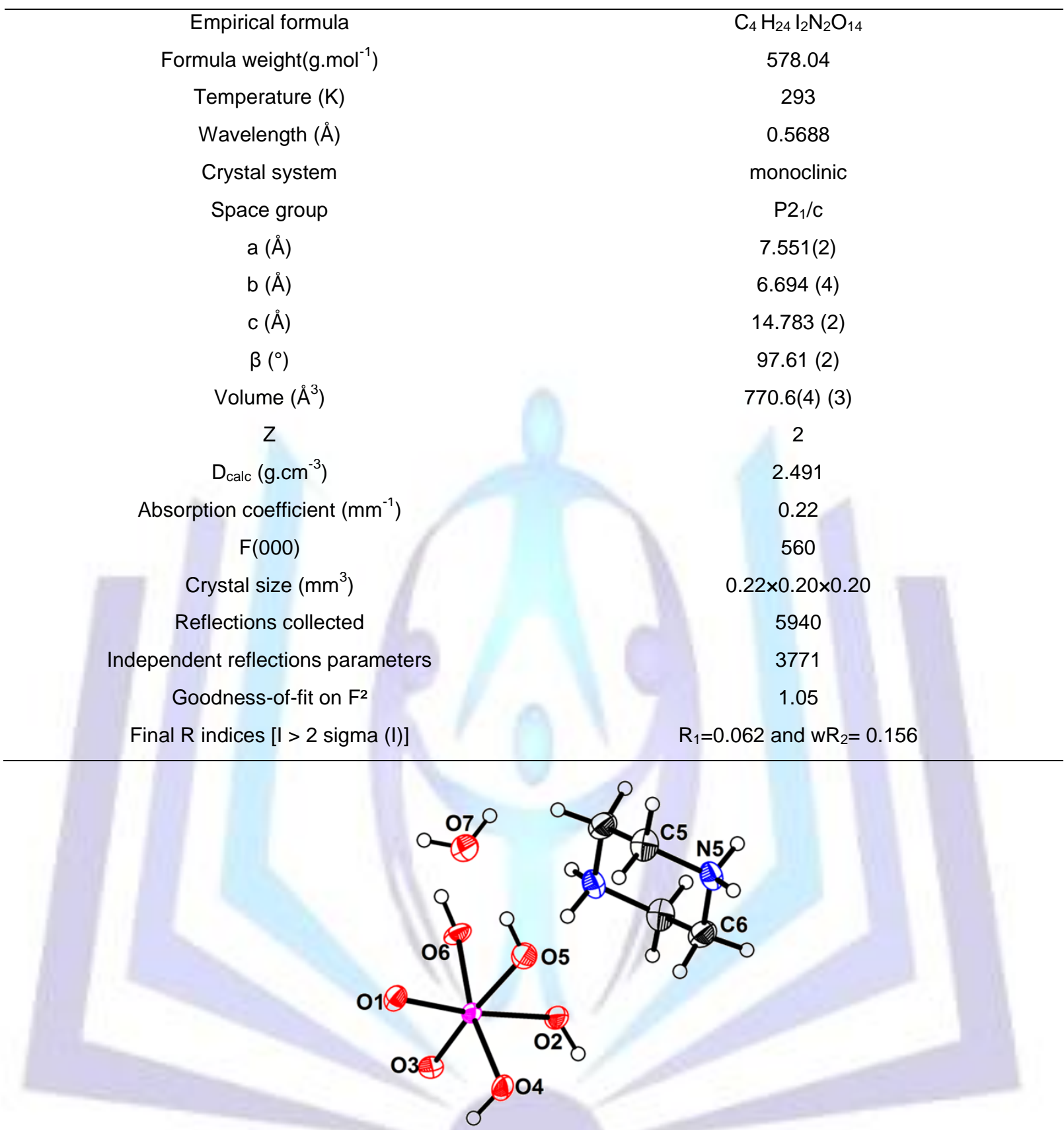

Figure 1. ORTEP view of $\left(\mathrm{C}_{4} \mathrm{H}_{12} \mathrm{~N}_{2}\right)\left(\mathrm{H}_{4} \mathrm{IO}_{6}\right)_{2} .2 \mathrm{H}_{2} \mathrm{O}$ showing $50 \%$ probability ellipsoids

Hydrogen bonds originating from the $\mathrm{H}_{4} \mathrm{IO}_{6}{ }^{-}$anions are expected to be much stronger than those originating from the

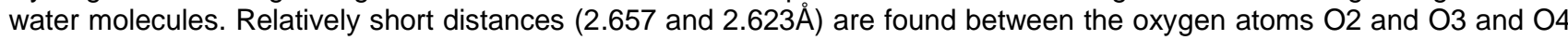
and $\mathrm{O} 1$ respectively, of the periodate ions (Table 3). Similar bonding are observed in inorganic compounds $\mathrm{Sr}\left(\mathrm{H}_{4} \mathrm{IO}_{6}\right)_{2} \cdot 3 \mathrm{H}_{2} \mathrm{O}$ [2]. So, in this case we expect strong hydrogen bonds which link periodate anions to built layers parallel to $(b, c)$ planes (Figure 3 ). In these latter the tetrahydrogenperiodate anions are associated so as to create $R_{1}{ }^{6}(18)$ and $\mathrm{R}_{1}{ }^{2}(8)$ graph-set motif. 


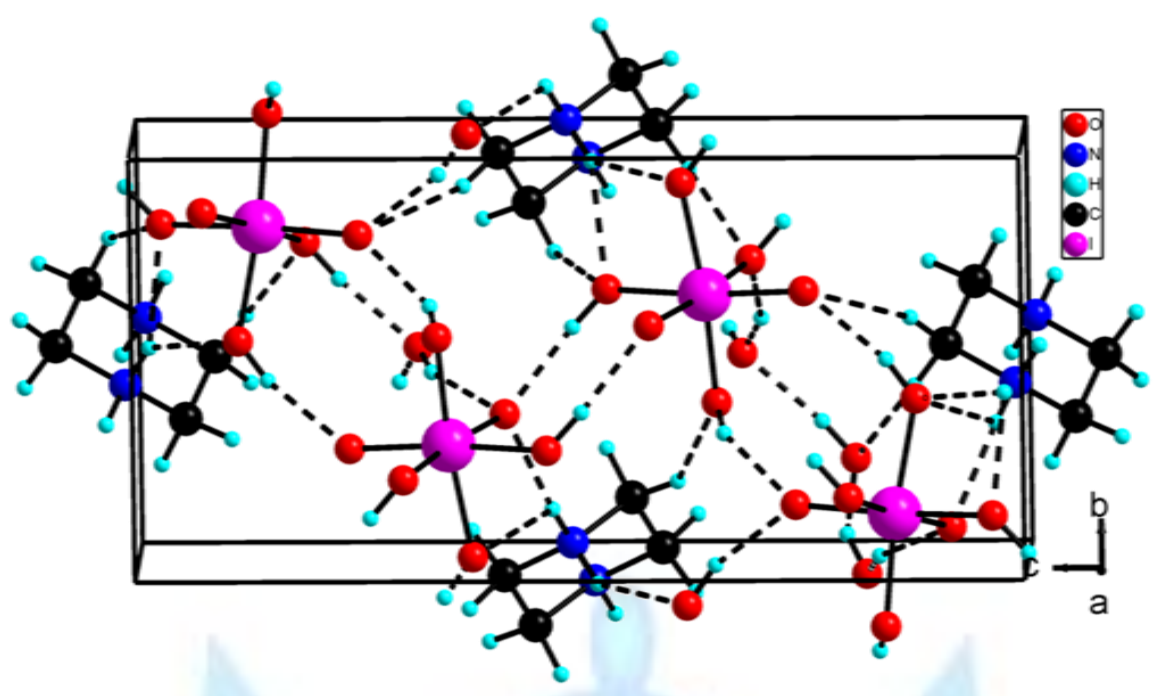

Figure 2. Crystal packing of $\left(\mathrm{C}_{4} \mathrm{H}_{12} \mathrm{~N}_{2}\right)\left(\mathrm{H}_{4} \mathrm{IO}_{6}\right)_{2} .2 \mathrm{H}_{2} \mathrm{O}$ with hydrogen bonds as dotted lines

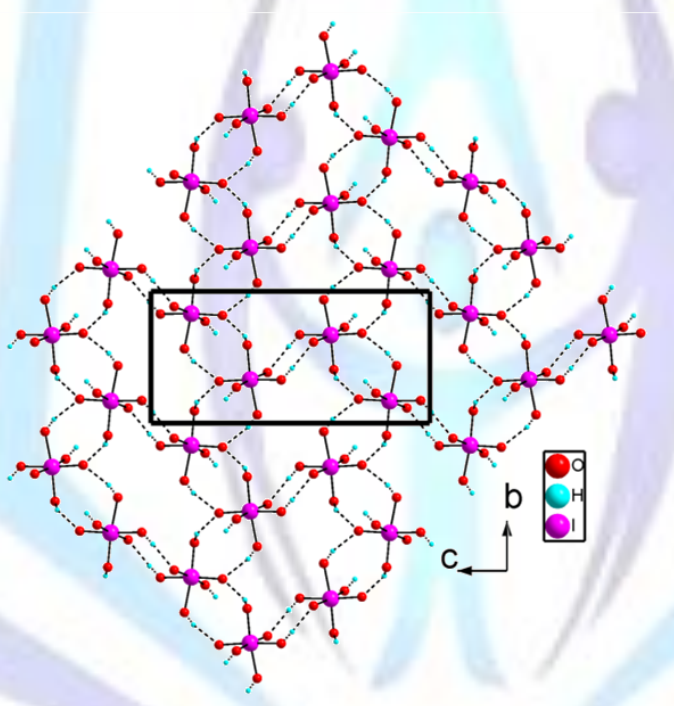

Figure 3. Two dimensional network of periodate anions

Table 2. Selected bond distances $(\AA)$ and angles $\left({ }^{\circ}\right)$ for $\left(\mathrm{C}_{4} \mathrm{H}_{12} \mathrm{~N}_{2}\right)\left(\mathrm{H}_{4} \mathrm{IO}_{6}\right)_{2.2} \mathrm{H}_{2} \mathrm{O}$

\begin{tabular}{|c|c|c|c|c|c|c|}
\hline $\mathrm{I}$ & $\mathrm{O}_{1}$ & $\mathrm{O}_{2}$ & $\mathrm{O}_{3}$ & $\mathrm{O}_{4}$ & $\mathrm{O}_{5}$ & $\mathrm{O}_{6}$ \\
\hline $\mathrm{O}_{1}$ & $\underline{1.806(4)}$ & 3.702 & 2.698 & 2.627 & 2.656 & 2.724 \\
\hline $\mathrm{O}_{2}$ & $172.22(17)$ & $\underline{1.904(4)}$ & 7.617 & 7.617 & $2.49(2)$ & 2.538 \\
\hline $\mathrm{O}_{3}$ & $96.17(17)$ & $91.16(18)$ & $\underline{1.820(3)}$ & 2.716 & 3.726 & 2.648 \\
\hline $\mathrm{O}_{4}$ & $94.91(15)$ & $87.16(15)$ & $94.04(17)$ & $\underline{1.891(3)}$ & 2.609 & 3.792 \\
\hline $\mathrm{O}_{5}$ & $91.16(18)$ & $81.46(18)$ & $172.55(16)$ & $86.61(17)$ & $\underline{1.912(3)}$ & 2.657 \\
\hline $\mathrm{O}_{6}$ & $94.06(14)$ & $83.26(15)$ & $90.25(16)$ & $169.18(14)$ & $87.91(17)$ & $\underline{1.916(3)}$ \\
\hline
\end{tabular}

The organic piperazinium dication lies at an inversion centre and adopts a typical chair geometry, as evidenced by the mean deviation $( \pm 0.038)$ from the least square plane, with normal valence bond lengths and angles [7], as observed in the structures of piperazinediium tetrachloridozincate [8] and piperazinediium tetrachloridozincate monohydrate [9]. 
Table 3. Principal intermolecular distances $(\AA)$ and bond angles $\left(^{\circ}\right)$ of the hydrogen bonding scheme

\begin{tabular}{lllll}
\hline $\mathrm{D}-\mathrm{H} \ldots \mathrm{A}$ & $\mathrm{D}-\mathrm{H}$ & $\mathrm{H} \ldots \mathrm{A}$ & $\mathrm{D} \ldots \mathrm{A}$ & $\mathrm{D}-\mathrm{H} \ldots \mathrm{A}$ \\
\hline $\mathrm{O}(4)-\mathrm{H}(4) \quad \ldots \mathrm{O}(1)$ & 0.82 & 1.90 & $2.626(5)$ & 147 \\
$\mathrm{~N}(5)-\mathrm{H}(5 \mathrm{~A}) \ldots \mathrm{O}(2)$ & 0.90 & 2.13 & $2.947(5)$ & 150 \\
$\mathrm{~N}(5)-\mathrm{H}(5 \mathrm{~A}) \ldots \mathrm{O}(6)$ & 0.90 & 2.26 & $3.004(6)$ & 140 \\
$\mathrm{~N}(5)-\mathrm{H}(5 \mathrm{~B}) \ldots \mathrm{O}(3)$ & 0.90 & 1.95 & $2.822(5)$ & 162 \\
$\mathrm{~N}(5)-\mathrm{H}(5 \mathrm{~B}) \ldots \mathrm{O}(6)$ & 0.90 & 2.51 & $3.099(6)$ & 124 \\
$\mathrm{O}(2)-\mathrm{H}(7) \ldots \mathrm{O}(3)$ & $0.85(5)$ & $1.83(6)$ & $2.656(5)$ & $162(7)$ \\
$\mathrm{O}(5)-\mathrm{H}(10) \ldots \mathrm{O}(7)$ & $0.83(7)$ & $1.72(7)$ & $2.546(7)$ & $172(9)$ \\
$\mathrm{O}(6)-\mathrm{H}(11) \ldots \mathrm{O}(1)$ & $0.81(6)$ & $1.98(7)$ & $2.680(5)$ & $145(7)$ \\
$\mathrm{O}(7)-\mathrm{H}(14) \ldots \mathrm{O}(3)$ & $0.84(5)$ & $1.95(6)$ & $2.740(6)$ & $156(7)$ \\
$\mathrm{O}(7)-\mathrm{H}(15) \ldots \mathrm{O}(5)$ & $0.85(9)$ & $2.01(8)$ & $2.767(6)$ & $148(10)$ \\
$\mathrm{C}(5)-\mathrm{H}(5 \mathrm{C}) \ldots \mathrm{O}(1)$ & 0.97 & 2.60 & $3.536(7)$ & 163 \\
$\mathrm{C}(5)-\mathrm{H}(5 \mathrm{D}) \ldots \mathrm{O}(5)$ & 0.97 & 2.47 & $3.384(7)$ & 157 \\
$\mathrm{C}(6)-\mathrm{H}(6 \mathrm{~A}) \ldots \mathrm{O}(2)$ & 0.97 & 2.58 & $3.301(7)$ & 132 \\
$\mathrm{C}(6)-\mathrm{H}(6 \mathrm{~B}) \ldots \mathrm{O}(4)$ & 0.97 & 2.43 & $3.262(7)$ & 144 \\
\hline
\end{tabular}

\subsection{Infrared Spectroscopy}

The infrared absorption spectrum of crystalline iodate is shown in Figure 4. To assign the IR peaks to vibrational modes, we examined the modes and frequencies observed in similar compounds [1]. The bands between $3758 \mathrm{~cm}^{-1}$ and $2843 \mathrm{~cm}$ ${ }^{1}$ correspond to the stretching vibrations of groups $\left(-\mathrm{NH}_{2}^{+}\right)$and $\left(-\mathrm{CH}_{2}^{-}\right)[10]$ and to the bending vibration of group $\left(\mathrm{H}_{2} \mathrm{O}\right)$ [11]. Bands appearing between 1592 and $1406 \mathrm{~cm}^{-1}$ are attributed to the bending vibrations of $\left(-\mathrm{NH}_{2}^{+}\right),\left(\mathrm{CH}_{2}\right),(\mathrm{OH})$ and $\left(\mathrm{H}_{2} \mathrm{O}\right)$ groups. The area between $1216-1090 \mathrm{~cm}^{-1}$ corresponds to the stretching vibrations $v(\mathrm{C}-\mathrm{N})$ and $v(\mathrm{C}-\mathrm{C})$.

Bands that lie between 1324 and $1142 \mathrm{~cm}^{-1}$ correspond to the bending of $\mathrm{IOH}$ group. The two strong bands at 635 and $761 \mathrm{~cm}^{-1}$ correspond to the stretching vibrations of $\mathrm{IO}(\mathrm{H})$. The area between 860 and $720 \mathrm{~cm}^{-1}$ is characteristic of the stretching vibration of $\mathrm{I}=\mathrm{O}$ and the area of fréqeunces $v<566 \mathrm{~cm}^{-1}$, corresponds to the bending vibration of $\mathrm{I}=\mathrm{O}$.

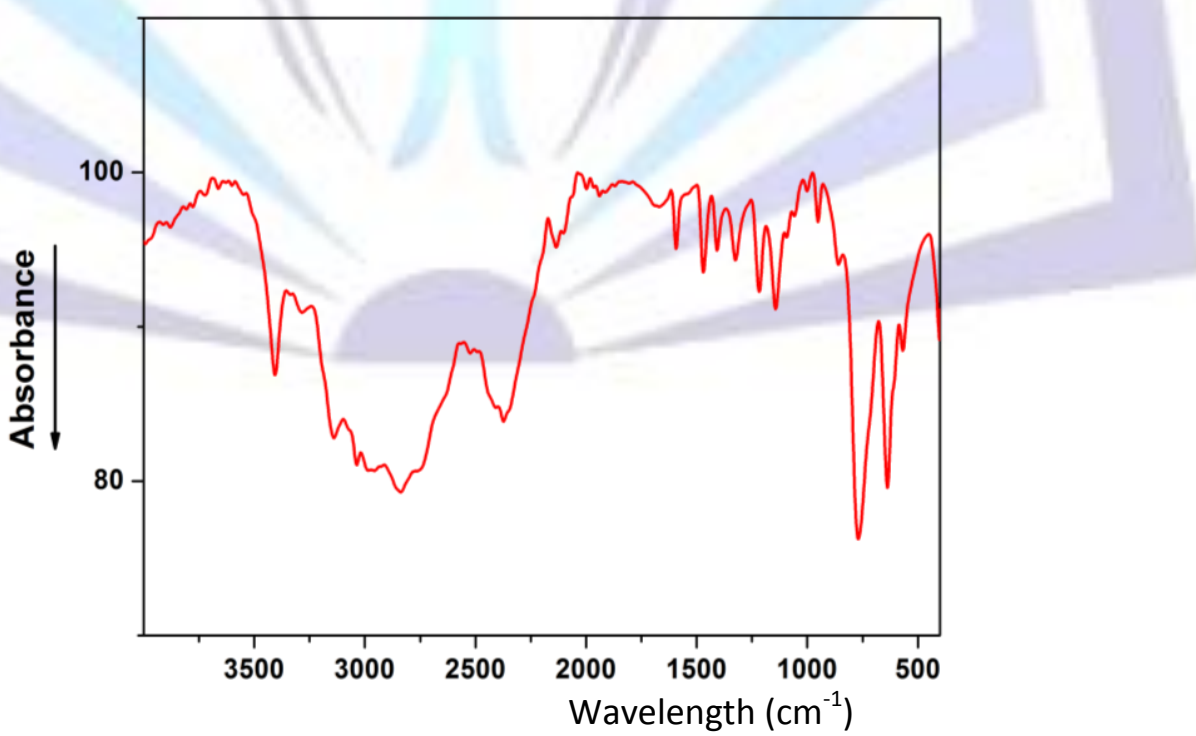

Figure 4. IR absorption spectrum of $\left(\mathrm{C}_{4} \mathrm{H}_{12} \mathrm{~N}_{2}\right)\left(\mathrm{H}_{4} \mathrm{IO}_{6}\right)_{2.2} \mathrm{H}_{2} \mathrm{O}$

\subsection{UV Absorption and Diffuse Reflectance}

The UV absorption spectrum revealed one little intensity band at $274 \mathrm{~nm}$. These band indicates the $\mathrm{n} \rightarrow \pi^{*}$ transition of the periodate $1 \mathrm{O} 6$ anions. Optical diffuse reflectance spectrum (Figure 5) indicates an optical band gap of $4 \mathrm{neV}$, hence, 
$\left(\mathrm{C}_{4} \mathrm{H}_{12} \mathrm{~N}_{2}\right)\left(\mathrm{H}_{4} \mathrm{IO}_{6}\right)_{2} .2 \mathrm{H}_{2} \mathrm{O}$ is a wide-band-gap of dielectric material. This value suggests that this compound could be used for optical applications in far UV region [12].

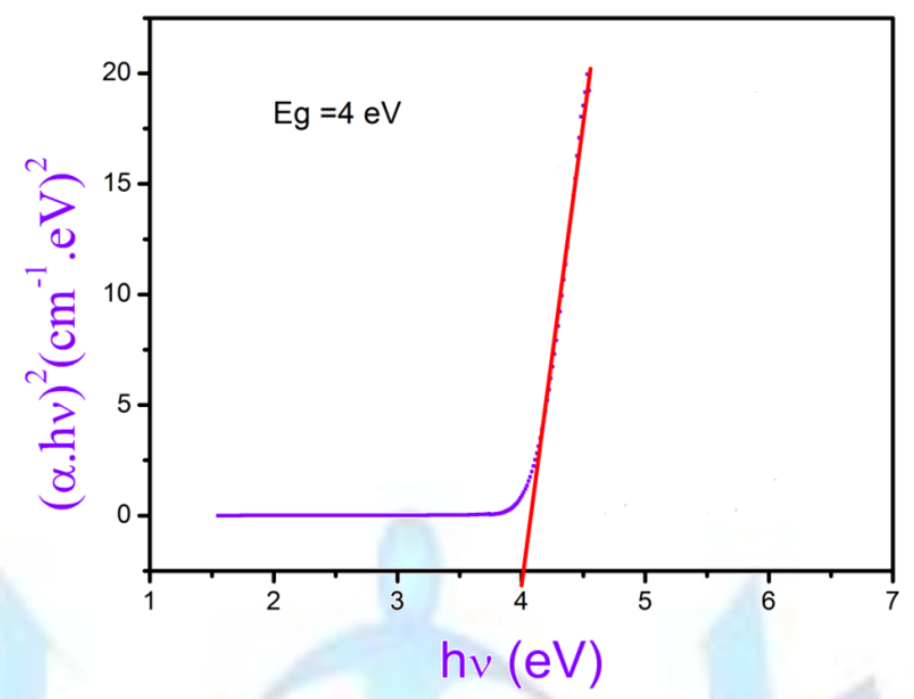

Figure 5. UV diffuse reflectance spectrum for $\left(\mathrm{C}_{4} \mathrm{H}_{12} \mathrm{~N}_{2}\right)\left(\mathrm{H}_{4} \mathrm{IO}_{6}\right)_{2} .2 \mathrm{H}_{2} \mathrm{O}$

\subsection{Thermogravimetric analysis}

The simulations TG-DTA analysis curves (Figure 6) of the title compound show that this material is thermally stable up to $364 \mathrm{~K}$ where it begins to dehydrate. In fact, the series of endothermic peaks, observed in the temperature range [363-403 $\mathrm{K}$ ] in DTA curve correspond to the dehydratation of the periodate to give a new phase of diperiodate to give a new phaseof diperiodate to diperiodate of piperazinium. This reaction is confirmed by the first weight loss (12\%) in the TG curve. This weight loss is very close to the percentage of four water molecules in the title compound

$$
\left[\mathrm{C}_{4} \mathrm{~N}_{2} \mathrm{H}_{12}\right]\left(\mathrm{IO}_{2}(\mathrm{OH})_{4}\right)_{2} .2 \mathrm{H}_{2} \mathrm{O} \longrightarrow\left[\mathrm{C}_{4} \mathrm{~N}_{2} \mathrm{H}_{12}\right]\left(\mathrm{H}_{4} \mathrm{I}_{2} \mathrm{O}_{10}\right)+4 \mathrm{H}_{2} \mathrm{O}
$$

The obtained anhydrous phase undergoes, in a wide temperature range [403-773 K]. Several phenomena represented by a series of peaks in the DTA curve and by two successive weight losses on the TG curve. The sum of these weight losses $(86 \%)$ corresponds to the percentage of the organic molecule in the studied compound $(87,2 \%)$. The organic molecules has suffered a pyrolysis and a combustion which give a gaseous release $\left(\mathrm{NH}_{3}, \mathrm{CO}_{2}, \mathrm{CO}, \mathrm{H} 2 \mathrm{O}\right)$ and which leave a liquid of diode contaminated of residue of carbon.

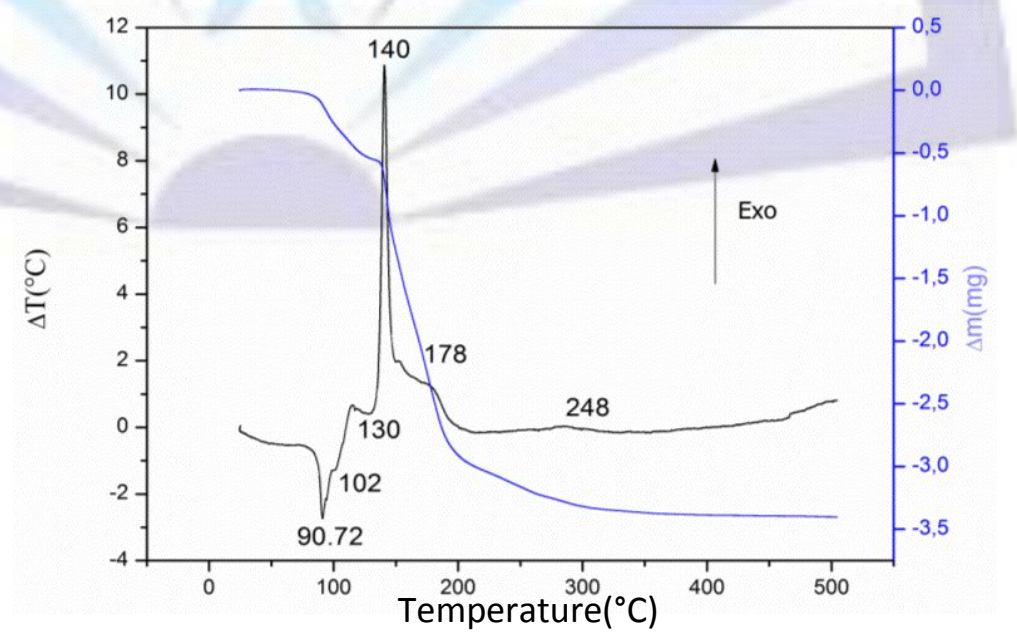

Figure 6. DTA-TGA diagram for $\left(\mathrm{C}_{4} \mathrm{H}_{12} \mathrm{~N}_{2}\right)\left(\mathrm{H}_{4} \mathrm{IO}_{6}\right)_{2} .2 \mathrm{H}_{2} \mathrm{O}$ 


\section{4 ${ }^{13} \mathrm{C}$ MAS-NMR analysis}

Figure 7 shows the ${ }^{13} \mathrm{C}$ MAS-NMR Spectrum of crystalline orthoperiodate $\left(\mathrm{C}_{4} \mathrm{H}_{12} \mathrm{~N}_{2}\right)\left(\mathrm{H}_{4} \mathrm{IO}_{6}\right)_{2} \cdot 2 \mathrm{H}_{2} \mathrm{O}$. This Spectrum is in good agreement with the X-ray structure. Indeed, it exhibits tow resonnance peaks at 43.57 and $41.05 \mathrm{ppm}$, with their corresponding satellite spinning side bands. These NMR components are related to the tow cristallographically inequivalent carbon which exist in the assymetric unit

\subsection{Conclusion}

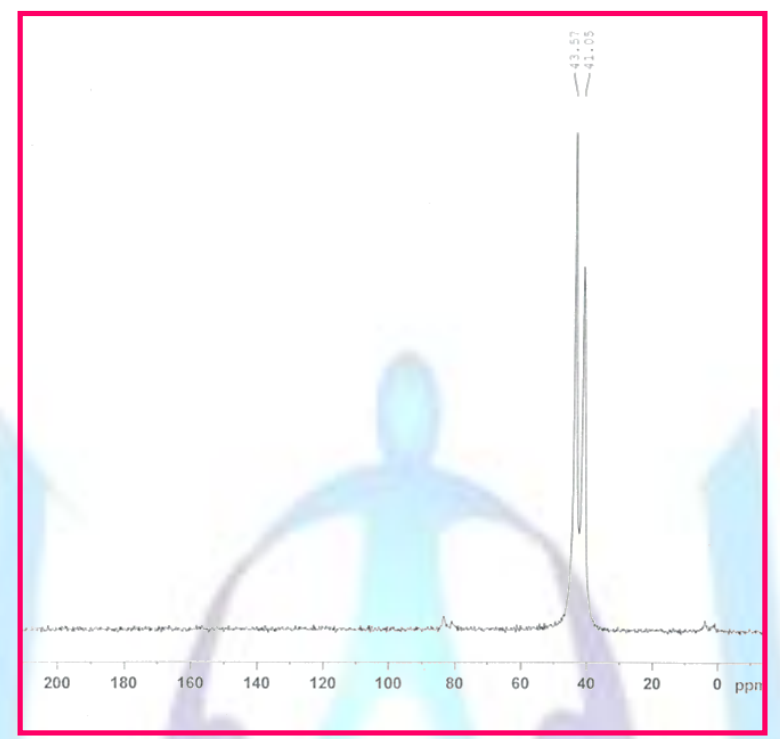

Figure 7. ${ }^{13} \mathrm{C}$ MAS-NMR Spectrum for $\left(\mathrm{C}_{4} \mathrm{H}_{12} \mathrm{~N}_{2}\right)\left(\mathrm{H}_{4} \mathrm{IO}_{6}\right)_{2} .2 \mathrm{H}_{2} \mathrm{O}$

The first organic cation periodate, $\left(\mathrm{C}_{4} \mathrm{H}_{12} \mathrm{~N}_{2}\right)\left(\mathrm{H}_{4} \mathrm{O}_{6}\right)_{2} \cdot 2 \mathrm{H}_{2} \mathrm{O}$, has been prepared and structurally characterized. The atomic arrangement of this periodate consists of a three-dimensional network of tetrahydrogenperiodate anions, water molecules and piperazinium dication connected by $\mathrm{Ow}-\mathrm{H} \ldots \mathrm{O}, \mathrm{N}-\mathrm{H} \cdots \mathrm{O}$ and $\mathrm{C}-\mathrm{H} \cdots \mathrm{O}$ hydrogen bonding interactions. Upon heating, this salt lost the crystallization water molecules then begins to degrade. The UV cut of wavelength indicates an energy gap $4 \mathrm{eV}$, a value indicating that this material could be used for optical applications in far UV region.

\section{REFERENCES}

[1] M. Alexandrova, H. Heuseler, Journal of molecular structure, (2004), 706,7

[2] T. Kraft, M. Jansen, Zeitschrift für anorganische und allgemeine Chemie, (1994), 620, 805

[3] J.G. Hu, Acta cristallographica, (2011), 67, 0472

[4] H.K.Fun, C.S.Yeap, C.S.Chidan Kumar, H.S.Yathirayan et B. Narayana, Acta Cristallographica, (2010), 66, 0361.

[5] H.R.Girisha, S. Naveen, K. Vinaya, M.A.Sridhar et K. S. Rangappa, Acta cristallographica,(2008),64, 0358.

[6] G.M. Sheldrick, Acta crystallographica, (2008), 64,112.

[7] F.H. Allen, O.Kennard, D.G. Watson, L. Brammer, et R. Taylor, journal of the Chemical Society, Perkin Transactions2, (1987), 1.

[8] A. V.Polishchuk, E.T. Karaserva et M. A. Pushilin, Acta crystallographica, (2009), 65, 1377

[9] R.Kefi, C.B.Nasr, Zeitschrift für Kristallographie - New Crystal Structures,(2005), 220,241

[10] Z.H.Liu, J.JZhang, W.J.Zhang, Inorganica chimica Acta, (2006), 69, 359

[11] Z. Liu, L. Li, J. Li, M. Hu, Journal of Alloysand compounds, (2005), 394, 277

[12] K.P.Blwvana, S.R Jeabas, materials letters journals, (2007),61,1489 